Я. А. Суходолов. Современное состояние внешнеторговой деятельности Республики Бурятия с Китаем

УДК $339.54(571.54+510)$

DOI: $10.18101 / 2304-4446-2019-4-81-88$

\title{
СОВРЕМЕННОЕ СОСТОЯНИЕ ВНЕШНЕТОРГОВОЙ ДЕЯТЕЛЬНОСТИ РЕСПУБЛИКИ БУРЯТИЯ С КИТАЕМ
}

\section{С Суходолов Яков Александрович}

кандидат экономических наук, доцент, Читинский институт (филиал) Байкальского государственного университета Россия, 672000, г. Чита, ул. Анохина, 56

E-mail: yakov.suhodolov@gmail.com

В статье рассмотрена современная специфика внешнеторговых связей Республики Бурятия с Китаем, который является основным внешнеторговым партнером региона. Представлены статистические данные о динамике объемов и основных тенденциях изменения товарной структуры экспортно-импортных операций Республики Бурятия, которая является экспортоориентированным субъектом Российской Федерации. Однако в товарной структуре экспорта региона основную долю занимают сырьевые группы товаров: каменный уголь, круглый лес и пиломатериалы, тогда как поставки продукции машиностроения носят нерегулярный характер. Развитие внешней торговли Республики Бурятия с Китаем связано с сохранением высокой доли продукции машиностроения в экспорте, а также увеличением объема экспорта готовой продукции, в первую очередь за счет создания новых производств, ориентированных на переработку добываемых на территории региона сырьевых ресурсов.

Ключевые слова: Республики Бурятия; Китай; внешняя торговля; экспорт; импорт; международное сотрудничество.

\section{Для цитирования}

Суходолов Я. А. Современное состояние внешнеторговой деятельности Республики Бурятия с Китаем // Вестник Бурятского государственного университета. Экономика и менеджмент. 2019. № 4. С. 81-88.

Республика Бурятия - субъект Российской Федерации, образованный 30 мая 1923 г. (Бурят-Монгольская АССР). Входит в состав Дальневосточного федерального округа (далее - ДФО). Площадь территории - 351,3 тыс. км ${ }^{2}$, что составляет 2,1\% территории России (14-е место среди регионов России). Численность населения (на 1 января 2019 г.) - 983,3 тыс. чел., что составляет 1,6\% населения России (55-е место среди регионов России). Плотность населения 2,8 чел. на $1 \mathrm{\kappa м}^{2}{ }^{1}$.

Республика Бурятия граничит с тремя субъектами Российской Федерации Республикой Тыва, Иркутской областью и Забайкальским краем. Также по территории региона проходит государственная граница с Монголией, протяженность которой составляет 1 213,6 км.

На территории региона расположено 4 пункта пропуска через государственную границу Российской Федерации - МАПП «Кяхта», ЖДПП «Наушки» и

\footnotetext{
${ }^{1}$ Федеральная служба государственной статистики Российской Федерации. URL: http://www.gks.ru
} 
ДАПП «Монды». Аэропорт «Байкал» (Улан-Удэ) является международным воздушным пунктом пропуска ${ }^{1}$.

Транспортная инфраструктура представлена участками Транссибирской и Байкало-Амурской железнодорожными магистралями. Участок Транссибирской магистрали имеет ответвление на Монголию (сообщением Улан-Удэ - Наушки). Протяженность железнодорожной сети составляет 2044 км. По территории региона проходит федеральная автомобильная дорога Р258 «Байкал» (сообщением Иркутск - Улан-Удэ - Чита), а также автомобильные дороги федерального значения А333 (Култук - Монды — граница с Монголией) и А340 (Улан-Удэ Кяхта - граница с Монголией). Протяженность автомобильных дорог общего пользования составляет 12,2 тыс. км.

Республика Бурятия располагает значительными запасами полезных ископаемых, в том числе до 95\% российских запасов нефрита, $48 \%$ - цинка, $32 \%$ - молибдена, 24\% - свинца, 20\% - вольфрама, $16 \%$ - плавикового шпата, $10 \%$ урана и $8 \%$ - золота ${ }^{2}$. Также регион богат лесными ресурсами, которые оцениваются в 2,2 млрд м ${ }^{3}$ (леса занимают 29,2 млн га, или $83,0 \%$ территории региона) и сельскохозяйственными угодьями (2,1 млн га земель сельскохозяйственного назначения, в том числе пашни - 0,7 млн га) $)^{3}$.

Установленная мощность энергосистемы региона составляет $1333,8 \mathrm{MB}$. Основной объем выработки электроэнергии (более 95\%) приходится на Гусиноозерскую ГРЭС (1 130 МВт) и Улан-Удэнскую ТЭЦ-1 (148 МВт) $)^{4}$ В перспективе возможно строительство Мокской (1 200 МВт) и Ивановской (210 МВт) ГЭС на р. Селенге.

Ведущими отраслями промышленности Республики Бурятия являются топливно-энергетический комплекс, машиностроение и металлообработка, лесная и деревообрабатывающая промышленность, горнодобывающая промышленность. На долю Республики Бурятия, по итогам 2016 г., пришлось 2,8\% валового регионального продукта Сибирского федерального округа, а также $0,3 \%$ валового регионального продукта России 5 .

Развитие международных торгово-экономических связей Республики Бурятия обусловлено такими факторами, как выгодное географическое положение, значительные запасы полезных ископаемых и лесных ресурсов, существующий промышленный комплекс, а также наличие железнодорожных и автомобильных магистралей.

По итогам 2018 г. объем внешнеторгового оборота региона составил 1 054,8 млн долл. (на 25,9 \% больше, чем в 2017 г.), экспорта — 950,0 млн долл. и импорта - 104,8 млн долл. Сальдо торгового баланса устойчиво положительное $+845,2$ млн долл.

\footnotetext{
${ }^{1}$ Министерство транспорта Российской Федерации. URL: https://www.mintrans.ru/storage/ app/media/perechen-punktov-propuska-20171512.pdf

${ }^{2}$ Инвестиционный портал Республики Бурятия URL: http://invest-buryatia.ru

${ }^{3}$ Там же.

${ }^{4}$ Официальный портал Республики Бурятия. URL: http://egov-buryatia.ru

${ }^{5}$ Российский статистический ежегодник. 2018: стат. сб. / Росстат. М., 2018. 694 с.
} 
Я. А. Суходолов. Современное состояние внешнеторговой деятельности Республики Бурятия с Китаем

Республика Бурятия относится к экспортно-ориентированным регионом Российской Федерации. В настоящее время доля экспорта во внешнеторговом обороте составляет около $90 \%$ (табл. 1).

Таблица 1

Внешнеторговый оборот Республики Бурятия за 2010-2018 гг., млн долл. *

\begin{tabular}{|l|l|l|r|r|r|r|r|r|r|}
\hline Показатель & $\mathbf{2 0 1 0}$ & $\mathbf{2 0 1 1}$ & \multicolumn{1}{|c|}{$\mathbf{2 0 1 2}$} & \multicolumn{1}{|c|}{$\mathbf{2 0 1 3}$} & \multicolumn{1}{|c|}{$\mathbf{2 0 1 4}$} & \multicolumn{1}{|c|}{$\mathbf{2 0 1 5}$} & \multicolumn{1}{|c|}{$\mathbf{2 0 1 6}$} & \multicolumn{1}{c|}{$\mathbf{2 0 1 7}$} & \multicolumn{1}{c|}{$\mathbf{2 0 1 8}$} \\
\hline ВТО & 978,0 & 920,6 & 1187,0 & 1395,5 & 1417,8 & 1597,9 & 1019,0 & 838,1 & 1054,8 \\
\hline Экспорт & 821,7 & 731,4 & 943,1 & 1247,6 & 1276,4 & 1493,6 & 960,0 & 755,0 & 950,0 \\
\hline Импорт & 156,3 & 189,2 & 243,9 & 147,9 & 141,4 & 104,3 & 59,0 & 83,1 & 104,8 \\
\hline Сальдо & 665,4 & 542,2 & 699,2 & 1099,7 & 1135,0 & 1389,3 & 901,0 & 671,9 & 845,2 \\
\hline
\end{tabular}

* Составлено по данным Сибирского таможенного управления. URL: http://stu.customs.ru.

За период 2010-2015 гг. отмечается увеличение объемов экспорта в 1,8 раза (с 821,7 до 1493,6 млн долл.) и снижение импорта в 1,5 раза (с 156,3 до 104,3 млн долл.). В 2016-2017 гг. в связи со снижением мировых цен на каменный уголь, а также сокращением количества зарубежных заказов авиационной техники, в том числе из-за прекращения поставок вертолетных двигателей ТВ3117 из Украины, произошло снижение объемов экспорта (до 755,0 млн долл.). В 2018 г. объем экспорт из Республики Бурятия вырос за счет роста мировых цен на каменный уголь, лесоматериалы и картон, а также увеличения поставок машиностроительной продукции (до 950,0 млн долл.).

По итогам 2018 г. Бурятская таможня перечислила в федеральный бюджет 9,0 млрд р. (табл. 2).

Таблииа 2

Поступления в федеральный бюджет от Бурятской таможни за 2010-2018 гг., млрд р.*

\begin{tabular}{|c|c|c|c|c|c|c|c|c|}
\hline $\mathbf{2 0 1 0}$ & $\mathbf{2 0 1 1}$ & $\mathbf{2 0 1 2}$ & $\mathbf{2 0 1 3}$ & $\mathbf{2 0 1 4}$ & $\mathbf{2 0 1 5}$ & $\mathbf{2 0 1 6}$ & $\mathbf{2 0 1 7}$ & $\mathbf{2 0 1 8}$ \\
\hline 1,6 & 2,3 & 2,5 & 1,5 & 1,7 & 1,9 & 2,0 & 2,5 & 9,0 \\
\hline
\end{tabular}

* Составлено по данным Сибирского таможенного управления. URL: http://stu.customs.ru.

В настоящее время в товарной структуре экспорта на долю минеральных продуктов приходится $68,2 \%$ (в основном каменный угль), древесины и целлюлознобумажной продукции - 16,2\% (лесоматериалы и картон) и машиностроительной продукции - 11,3\%. На прочие товарные группы приходится 4,3\%.

Товарная структура импорта представлена продовольственными товарами $53,4 \%$, продукцией машиностроения - 27,9\%, продукцией химической промышленности $-8,7 \%$, текстилем, текстильными изделиями и обувью $-3,7 \%$ и металлами и изделиями из них - 3,4\%. На прочие товарные группы приходится $2,9 \%$.

В 2018 г. внешнеторговые операции Республики Бурятия осуществлялись с 60 странами мира. На страны дальнего зарубежья приходится 98,3\% общего объема внешнеторгового оборота (1 037,3 млн долл.), на страны СНГ $-1,7 \%$ (17,5 млн долл.). По итогам 2018 г. основными внешнеторговыми партнерами Республики Бурятия стали Китай $(37,4 \%)$, Япония $(18,8 \%)$, Южная Корея $(13,2 \%)$, Перу $(6,3 \%)$, Монголия $(4,3 \%)$ и Индия $(4,2 \%)$ (табл. 3$)$. 
Внешнеторговый оборот Республики Бурятия с некоторыми странами мира за 2010-2018 гг., \% *

\begin{tabular}{|l|c|c|c|c|c|c|c|c|c|}
\hline \multicolumn{1}{|c|}{ Страна } & $\mathbf{2 0 1 0}$ & $\mathbf{2 0 1 1}$ & $\mathbf{2 0 1 2}$ & $\mathbf{2 0 1 3}$ & $\mathbf{2 0 1 4}$ & $\mathbf{2 0 1 5}$ & $\mathbf{2 0 1 6}$ & $\mathbf{2 0 1 7}$ & $\mathbf{2 0 1 8}$ \\
\hline Китай & 33,7 & 49,3 & 31,2 & 53,5 & 40,9 & 14,7 & 24,2 & 35,5 & 37,4 \\
\hline Япония & 0,2 & 0,3 & 10,5 & 13,1 & 9,1 & 7,4 & 12,8 & 17,9 & 18,8 \\
\hline Южная Корея & - & 0,2 & 10,1 & 10,2 & 9,1 & 5,4 & 7,5 & 15,6 & 13,2 \\
\hline Тайвань & 0,0 & 0,0 & 2,9 & 2,8 & 2,9 & 4,4 & 5,1 & 9,8 & 7,8 \\
\hline Перу & - & 8,0 & 0,3 & 0,1 & 10,9 & 21,5 & 0,8 & 0,1 & 6,3 \\
\hline Монголия & 5,0 & 6,8 & 3,8 & 3,0 & 2,4 & 2,0 & 3,4 & 4,9 & 4,3 \\
\hline Индия & - & - & - & 0,0 & 0,3 & 1,7 & 2,8 & 2,5 & 4,2 \\
\hline Вьетнам & - & 2,3 & 0,1 & 0,0 & 0,1 & 0,9 & 2,9 & 1,8 & 2,0 \\
\hline Гонконг & - & - & 0,7 & 0,5 & 0,8 & 1,3 & 2,8 & 2,4 & 1,9 \\
\hline Малайзия & 0,1 & 0,1 & 0,1 & 0,9 & 2,2 & 1,1 & 1,4 & 2,1 & 1,7 \\
\hline Чехия & 0,4 & 0,7 & - & 0,6 & 0,6 & 0,4 & 0,3 & 0,5 & 1,0 \\
\hline Прочие страны & 60,6 & 32,3 & 40,3 & 15,3 & 20,7 & 39,2 & 36,0 & 6,9 & 1,4 \\
\hline \multicolumn{1}{|c|}{ Всего } & 100,0 & 100,0 & 100,0 & 100,0 & 100,0 & 100,0 & 100,0 & 100,0 & 100,0 \\
\hline
\end{tabular}

* Составлено по данным Сибирского таможенного управления. URL: http://stu.customs.ru.

Высокая доля прочих стран в некоторые годы связана с тем, что из Республики Бурятия осуществлялись крупные разовые экспортные поставки в различные страны мира (в основном вертолетов и запасных частей к ним). Так, в 2010 г. такие экспортные поставки осуществлялись в Кению (38,1 млн долл.), ОАЭ (32,5 млн долл.), Эквадор (22,4 млн долл.) и Пакистан (17,7 млн долл.). В 2011 г. - ОАЭ (30,4 млн долл.), Словакию (22,9 млн долл.) и Кению (22,5 млн долл.). В 2012 г. - Гану (71,6 млн долл.), ОАЭ (56,4 млн долл.), Бангладеш (44,3 млн долл.), Мьянму (15,3 млн долл.) и Судан (31,4 млн долл.). В 2013 г. - Словакию (64,0 млн долл.) и Бразилию (12,3 млн долл.). В 2014 г. - Ирак (169,8 млн долл.). В 2015 г. — Ирак (339,7 млн долл.), Бангладеш (89,2 млн долл.) и Анголу (82,4 млн долл.). В 2016 г. Бангладеш (126,3 млн долл.) и Анголу (154,9 млн долл.). В 2017 г. - Пакистан (28,9 млн долл.).

В настоящее время основным внешнеторговым партнером Республики Бурятия является Китайская Народная Республика. По итогам 2018 г. доля Китая во внешние торговли региона составила 37,4\% (394,2 млн долл.), в экспорте $34,6 \%$ (328,4 млн долл.), в импорте - 62,9\% (65,9 млн долл.). Сальдо торгового баланса традиционно положительное и составляет $+262,5$ млн долл. (табл. 4).

Таблица 4

Внешнеторговый оборот Республики Бурятия с Китаем за 2010-2018 гг., млн долл. *

\begin{tabular}{|l|r|r|r|r|r|r|r|r|r|}
\hline Показатель & \multicolumn{1}{|c|}{2010} & \multicolumn{1}{c|}{2011} & \multicolumn{1}{c|}{2012} & \multicolumn{1}{|c|}{2013} & \multicolumn{1}{c|}{2014} & \multicolumn{1}{c|}{2015} & \multicolumn{1}{c|}{2016} & \multicolumn{1}{c|}{2017} & 2018 \\
\hline ВТО & \multicolumn{1}{|c|}{329,1} & 453,5 & 370,2 & 746,8 & 579,5 & 234,4 & 246,5 & 297,8 & 394,2 \\
\hline Экспорт & 266,2 & 384,1 & 321,2 & 704,6 & 543,9 & 202,3 & 208,4 & 244,8 & 328,4 \\
\hline Импорт & 62,9 & 69,4 & 49,0 & 42,2 & 35,6 & 32,1 & 38,1 & 53,0 & 65,9 \\
\hline Сальдо & 203,3 & 314,6 & 272,3 & 662,3 & 508,2 & 170,2 & 170,3 & 191,8 & 262,5 \\
\hline
\end{tabular}

* Составлено по данным Сибирского таможенного управления. URL: http://stu.customs.ru. 
Я. А. Суходолов. Современное состояние внешнеторговой деятельности Республики Бурятия с Китаем

На долю Республики Бурятия во внешней торговле России с Китаем в 2018 г. пришлось $0,4 \%$ (экспорта - 0,6\% и импорта $-0,1 \%$ ).

По итогам 2018 г. основную долю в товарной структуре экспорта Республики Бурятия в Китай занимают минеральные продукты - 43,4\% (экспорт каменного угля из региона на рынки стран АТР в основном осуществляется АО «Разрез Тугнуйский», которое является дочерней компанией $\mathrm{AO}$ «Сибирская угольная энергетическая компания»), древесина и целлюлозно-бумажная продукция $37,8 \%$ (в том числе круглый лес и пиломатериалы - 30,8\%, картон $-7,0 \%$ ). Ocновным производителем и экспортером картона на территории Республики Бурятия является ОАО «Селенгинский целлюлозно-картонный комбинат». На долю продукции машиностроения приходится лишь 0,03\% общего объема экспорта (табл. 5).

Таблица 5

Товарная структура экспорта

Республики Бурятия в Китай за 2013-2018 гг., \% *

\begin{tabular}{|l|r|r|r|r|r|r|}
\hline \multicolumn{1}{|c|}{ Товарная группа } & \multicolumn{1}{|c|}{$\mathbf{2 0 1 3}$} & \multicolumn{1}{|c|}{$\mathbf{2 0 1 4}$} & \multicolumn{1}{c|}{$\mathbf{2 0 1 5}$} & \multicolumn{1}{c|}{$\mathbf{2 0 1 6}$} & \multicolumn{1}{c|}{$\mathbf{2 0 1 7}$} & \multicolumn{1}{c|}{$\mathbf{2 0 1 8}$} \\
\hline Минеральные продукты & 41,9 & 48,9 & 60,6 & 46,3 & 56,9 & 43,4 \\
\hline $\begin{array}{l}\text { Древесина и целлюлозно- } \\
\text { бумажная продукция }\end{array}$ & 10,6 & 14,6 & 33,2 & 38,5 & 40,8 & 37,8 \\
\hline Продукция машиностроения & 0,3 & 35,2 & 3,8 & 13,6 & 0,2 & 0,03 \\
\hline Прочее & 47,2 & 1,3 & 2,5 & 1,7 & 2,1 & 18,8 \\
\hline Всего & 100,0 & 100,0 & 100,0 & 100,0 & 100,0 & 100,0 \\
\hline
\end{tabular}

* Составлено по данным Сибирского таможенного управления. URL: http://stu.customs.ru.

За период 2013-2018 гг. произошло увеличение доли минеральных продуктов (с 41,9 до 43,4\%), древесины и целлюлозно-бумажной продукции (с 10,6 до 37,8 \%). Доля продукции машиностроения в экспорте неустойчива, так как связана с деятельностью АО «Улан-Удэнский авиационный завод» (входит в холдинг АО «Вертолеты России», который является дочерней компанией ГК «Ростех»), осуществляющий реализацию контрактов по поставке авиационной техники.

По итогам 2018 г. товарная структура импорта в Республику Бурятия из Китая сохраняет потребительскую направленность. На долю продовольственных товаров приходится $61,1 \%$ (в том числе на овощи - 33,1\% и фрукты - 28,0\%), продукции машиностроения - 25,3\% (в том числе промышленное оборудование - 21,3 \% и транспортные средства - 4,0 \%) и металлов и изделий из них $1,3 \%$ (табл. 6). 
Товарная структура импорта из Китая в Республику Бурятия за 2013-2018 гг., \% *

\begin{tabular}{|l|r|r|r|r|r|r|}
\hline \multicolumn{1}{|c|}{ Товарная группа } & \multicolumn{1}{|c|}{$\mathbf{2 0 1 3}$} & \multicolumn{1}{|c|}{$\mathbf{2 0 1 4}$} & \multicolumn{1}{c|}{$\mathbf{2 0 1 5}$} & \multicolumn{1}{c|}{$\mathbf{2 0 1 6}$} & \multicolumn{1}{c|}{$\mathbf{2 0 1 7}$} & \multicolumn{1}{c|}{$\mathbf{2 0 1 8}$} \\
\hline Продовольственные товары & 39,9 & 41,0 & 53,3 & 62,4 & 44,2 & 61,1 \\
\hline Продукция машиностроения & 35,3 & 28,8 & 24,8 & 16,2 & 34,4 & 25,3 \\
\hline Металлы и изделия из них & 5,9 & 6,3 & 5,4 & 3,8 & 6,6 & 1,3 \\
\hline Прочее & 18,8 & 23,8 & 16,5 & 17,6 & 14,8 & 12,3 \\
\hline Всего & 100,0 & 100,0 & 100,0 & 100,0 & 100,0 & 100,0 \\
\hline
\end{tabular}

* Составлено по данным Сибирского таможенного управления. URL: http://stu.customs.ru.

За период 2013-2018 гг. произошло увеличение доли продовольственных товаров (с 39,9 до 61,1\%), а также снижение доли продукции машиностроения (с 35,3 до 25,3 \%) и металлов и изделии из них (с 5,9 до 1,3 \%).

В настоящее время внешняя торговля является важным фактором для социально-экономического развития Республики Бурятия и характеризуется следующими особенностями:

- объем экспорта значительно превышает объем импорта (среднегодовая доля экспорта в обороте за 2010-2018 гг. составляет около 88,2\%, импорта $11,8 \%$;

- сальдо внешнеторгового баланса за период 2010-2018 гг. положительное, в том числе в торговле с Китаем;

- в экспорте преобладают сырьевые группы товаров - 78,9\% (минеральные продукты - 68,2\%, лесоматериалы необработанные - 9,7 \% и лесоматериалы обработанные - $1,0 \%$ ), а в импорте продовольственные товары $(53,4 \%)$, продукция машиностроения $(27,9 \%)$ и химической промышленности $(8,7 \%)$;

- высока доля готовой продукции в экспорте - 14,6 \%, в том числе продукции машиностроения - 11,3\% и целлюлозно-бумажной промышленности $3,3 \%$;

- преобладание стран АТР во внешнеторговом обороте (Китай, Япония, Южная Корея, Вьетнам и Малайзия, а также Монголия);

- основным внешнеторговым партнером является Китай (среднегодовая доля Китая во внешнеторговом обороте за период 2010-2018 гг. составляет 35,6 \%, в экспорте - 35,6 \%, в импорте - 41,4 \%);

- в товарной структуре экспорта Республики Бурятия непосредственно в Китай преобладает товарная группа - минеральные продукты (среднегодовая доля которой за период 2013-2018 гг. составила 59,6\%). Доля продукции целлюлознобумажной промышленности за аналогичный период составила $35,1 \%$. На долю продукции машиностроения пришлось 10,6\%. При этом в 2017-2018 гг. объем поставок авиационной техники и запасных частей к ней был незначительным.

Экспортная ориентация является важной для социально-экономического развития Республики Бурятия [1;3]. Однако достигнутый уровень внешнеторгового сотрудничества Республики Бурятия с Китаем не обеспечивает должного использования имеющихся в регионе конкурентных преимуществ $[2 ; 4 ; 6]$. В ближайшей перспективе развитие внешней торговли региона будет связано с активиза- 
цией освоения природных ресурсов, что, в свою очередь, повлечет за собой сохранение сырьевых групп товаров в экспорте (каменного угля, продукции лесопромышленного комплекса, вольфрамового концентрата и др. $)^{1}$ [7].

Важной задачей развития несырьевого экспорта Республики Бурятия является сохранение высокой доли продукции машиностроения в экспорте [5]. Одним из направлений модернизации машиностроительного комплекса региона может стать организация производств в рамках реализации совместного проекта по созданию перспективного российско-китайского вертолета.

Вместе с тем диверсификация товарной структуры внешней торговли Республики Бурятия с Китаем за счет создания новых перерабатывающих производств, ориентированных на увеличение глубины переработки сырья, в том числе сельскохозяйственного (в целях организации экспорта концентратов цинка, свинца, пирита и редкоземельных металлов, продукции лесопромышленного и агропромышленного комплекса, а также ювелирной продукции и изделий из нефрита и др.), является наиболее перспективным направлением развития и повышения эффективности внешней торговли Республики Бурятия.

Повышение доли инновационной продукции с высокой степенью передела и уход от сырьевой структуры экспорта, а также производственнопотребительского характера импорта позволят повысить качество внешнеэкономической деятельности и откроет новые возможности в торгово-экономических и инвестиционных отношениях региона с Китаем.

\section{Литература}

1. Башкуева Е. Ю., Атанов Н. И. Внешнеэкономическое сотрудничество Республики Бурятия и Забайкальского края с Китаем и Монголией: состояние и проблемы // Вестник Бурятского государственного университета. Экономика и менеджмент. 2014. № 2. С. 32 41.

2. Ковальчук Л. Б., Суходолов Я. А. Процессный подход как методологическая основа экономической интеграции Забайкальского края и сопредельных территорий КНР // Известия Байкальского государственного университета. 2018. Т. 28, № 2. С. 292-299.

3. Намжилова В. О. Особенности современного развития внешнеторговых связей Республики Бурятия // Вестник Бурятского научного центра Сибирского отделения Российской академии наук. 2017. № 1(25). С. 127-134.

4. Суходолов А. П., Козырская И. Е., Кузьмин Ю. В. Экономические риски российской экономики и национальные интересы в треугольнике Россия - Монголия - Китай // Евразийский интеграционный проект: цивилизационная идентичность и глобальное позиционирование: материалы междунар. Байкальского форума / под науч. ред. Е. Р. Метелевой. Иркутск, 2018. С. 395-402.

5. Суходолов Я. А. Российско-китайское внешнеторговое сотрудничество как фактор развития экономики России: дис. ... канд. экон. наук. Ростов н/Д., 2016. 216 с.

6. Цыренова Е. Д., Бордоев Д. Г., Цыренов А. Р. Байкальский регион в экономическом и социальном развитии России // Вестник ВСГУТУ. 2015. № 4(55). С. 107-112.

7. Шаралдаева И. А., Сыренова С. Б. Анализ внешнеэкономической деятельности региона (на примере Республики Бурятия) // Вестник ВСГУТУ. 2016. № 6(63). С. 153-157.

\footnotetext{
${ }^{1}$ Россия - Сибирь. 2050: глобальные тренды и «окна возможностей»: аналит. докл. / под ред. В. С. Ефимова. Красноярск: Изд-во Сиб. федер. ун-та, 2018. 88 с.
} 


\section{CURRENT STATE OF BURYATIA'S FOREIGN TRADE WITH CHINA}

Yakov A. Sukhodolov

Cand. Sci. (Econ.), A/Prof.,

Chita Institute (branch) of Baikal State University

56 Anokhina St., Chita 672000, Russia

E-mail: yakov.suhodolov@gmail.com

The article considers the current state of the foreign trade of the Republic of Buryatia with China as a main foreign trade partner of the region; presents the statistics on the dynamics of volumes and main trends in the commodity composition of export-import operations of the republic. Buryatia is an export-oriented subject of the Russian Federation, but the main share in the commodity composition of the region's export is occupied by raw materials: coal, roundwood and timber, while the supply of engineering products is irregular. The development of Buryatia's foreign trade with China is associated with the preservation of a high share of engineering products in exports, as well as with an increase of finished products export, primarily due to the creation of new industries focused on the processing of raw materials extracted in the region.

Keywords: the Republic of Buryatia; China; foreign trade; export; import; international cooperation. 